\title{
A Christmas Legend from the Ghetto (Vánoční legenda z ghetta)
}

\author{
Author: František Kafka
}

First Published: 1946

About the Author: František Kafka (1909-1991) came from a cultivated Czech-Jewish family, his father was a doctor. Kafka graduated with a degree in law from Charles University in Prague in 1933 and worked as a lawyer and journalist. In October of 1941, he was sent with the transport of the Czech Jews to the Lodz Ghetto (Litzmannstadt Ghetto). Only 80 people from 1000 Jews survived in this transport. Kafka was deported from Lodz to the forced labour camp Skarżysko-Kamienna and later to Częstochowa where he was liberated in January 1945. After the liberation, he crossed the Tatra mountains to Poprad in Slovakia and joined the Czechoslovak Army Corps that was a part of the Red Army. In April 1945, he became secretary in the first Czechoslovak postwar government, established in Košice. From 1945 to 1954 he was an official in the Ministry of Industry in Prague. After a severe illness, Kafka retired in 1961. He concentrated on researching at Jewish Studies, German literature in the Czech lands (Werfel, Kafka, Brod, Weiskopf) as well as translating (Franz Kafka's letters, Franz Werfel, Peter Lotar) and writing. His son Vladimír Kafka (1937-2005) wrote poems, on the topic of the Holocaust among others.

Further Important Publications: Žiznivá poutnice (1947, A Thirsty Pilgrimess; short stories); Krutá léta (The Cruel Years, 1963; novel); Hanuš Fantl - neumlčený básník (Hanuš Fantl - A Poet that Was Not Silenced, 1964; the study and anthology of poems written by the Jewish Czech poet); Básník Bernard Kosiner a jeho svět (The Poet Bernard Kosiner and His World, 1964; a study about the Jewish Czech poet and philosopher and anthology of his works); Hanuš Thein (Hanuš Thein, 1971; a study about the Jewish Czech opera singer and theatre director); Velký pražský rabi Jehuda Löw. Nová vyprávění $z$ doby renesance (The Great Rabbi Judah Loew of Prague: New Tales from the Time of the Renaissance, 1994, anthology).

\section{Content and Interpretation}

This very short story (about ten standard pages) was written in the Lodz Ghetto where the author was interned, in December of 1942. Nevertheless, it doesn't describe the situation of the prisoners but it is more of a fairy tale or legend. The story takes place first in Heaven, later in the Lodz Ghetto, on Christmas Eve, December 24, 1942. St. Peter, a porter in Heaven, is sitting on a chair and reading the news. He knows about the cruel war raging on Earth. Suddenly Peter is sent to the throne of God. Jesus tells him to get ready for a journey, they will fly to Earth together. During the flight, Peter sees two triangle pictures in front of him. In the first triangle he can watch famous and heroic scenes from the Jewish past (Adam's awakening by Eve's side, Isaac 
being sacrificed, Jacob's fight with the angel, Moses and the burning bush, David singing and playing the lute, the building of Solomon's Temple, etc.). In the second triangle, dark fates of the Jews are to be seen (the killing of Abel, Sodom and Gomorrah, selling Joseph to slavery, the golden calf, Uriah's wife in David's palace, Calvary, the destruction of the Temple). Jesus and Peter fly down to the Lodz Ghetto. They are able to follow, invisible for others, the desperate situation of the imprisoned Jews who are dying of hunger, poor hygiene and brutal Nazi treatment. Jesus doesn't answer Peter's questions why is this happening and why these innocent people must suffer and die. In the middle of the night, Jesus and Peter enter a poor dingy room smelling of rotten turnips where seven people are sleeping. Jesus remains by the bed of a thirty-yearold man. Suddenly Jesus's figure is illuminated by light, the man can see him and sits up in his bed. The man recognises Jesus and thanks him for revealing himself today. He remembers his wife and little son in his native country who believe in Jesus Christ as he does and says he was sent here because of the faith of his ancestors but he doesn't understand the language and habits of his fellow prisoners (Yiddish and Orthodox Jewish rituals). "Why do I have to suffer so much, so much to remember [...]? Why, my Lord?” (Kafka, 1947, p. 130).

Jesus doesn't answer, he just runs his hand over his face and the man falls asleep again. On the way back to Heaven, Peter asks Jesus why they have visited just this man. Jesus says:

"Specifically he is chosen to describe the suffering of his tribe. [...] From his fellow countrymen only he will survive this whirlwind and return to his wife and child. And he will bear witness to everything that he has survived, suffered and watched [...] Because he is a poet...!” (p. 131).

\section{Main Topics and Problems}

The text is dated "December of 1942". Undoubtedly, the description of the situation in the Lodz Ghetto is based on the author's own experiences. In the character of the sleeping man who is visited by Jesus and chosen to tell about the ghetto it is possible to find some František Kafka's autobiographical features (his distance to the Orthodox Judaism, his family in the Czech lands, his poetic gift that is visible in his early works). Although the man is a Christian, he comes from a Jewish family. So it is possible to understand Jesus' words about bearing witness as a continuation of an old tradition of Jewish Memorbücher (works dedicated to the memory of martyrs written in Jewish communities in Central Europe, existing from the 13th century) and the even much older Book of Deuteronomy, the fifth book in the Hebrew as well as Christian Bible (Assmann, 1997, pp. 212-228).

On the other hand, Jewish or Christian spiritual symbols are used very often in Holocaust literature. Nazi concentration camps, ghettos or slave labour camps are compared to Hell, prisoners to martyrs, their liberation to redemption etc. Nevertheless, the idea of Jesus' visit of the ghetto is very original. An analogy can be drawn to the short story of Otto Weiss (1898-1944) $\rightarrow$ And God Saw That It Was Bad written in the 
Theresienstadt Ghetto in 1943. Here God descends from Heaven to Earth to make sure how the Jews are living in Theresienstadt. He appears in the figure of an ordinary prisoner. However, he is helpless and returns to Heaven in desperation. Weiss' short prose is heretical in fact by denying God's omnipotence. Kafka's text is closer to a traditional Jewish or Christian legend.

A Christmas Legend from the Ghetto was published first as a limited edition in 1946. One year later, it became a part of Kafka's collection A Thirsty Pilgrimess which contains mainly stories from the time before the author had been summoned to the transport, but also with one other story from the Nazi labour camp.

In the 1960s, Kafka's long novel The Cruel Years was edited. Its topic is the stay of Czech Jews and other prisoners in the Lodz Ghetto. Unlike A Christmas Legend from the Ghetto, The Cruel Years depicts the ghetto in a more realistic manner including authentic characters such as the head of the Jewish council, Chaim Rumkowski (A. Bart's $\rightarrow$ The Flytrap Factory), or the chief of the Nazi administration, Hans Biebow.

\section{Cited Works}

Assmann, J. (1997). Das kulturelle Gedächtnis. Schrift, Erinnerung und politische Identität in den frühen Hochkulturen. 2nd ed. München: C. H. Beck. Kafka, F. (1947). Žiznivá poutnice. Praha: Nakladatelské družstvo Máje, pp. 121-131.

\section{Further References}

Babler, O. F. (1979). František Kafka - sedmdesátník. Věstník židovských náboženských obcí v Československu, 41(11), p. 6. Fuks, L. (1984). Mladý pětasedmdesátník. Hlas revoluce, 38(49), p. 6. Holý, J. (2016). Šoa ve fikční próze do konce šedesátých let. In: J. Holý, ed., Cizí i blízcí. Židé, literatura, kultura v českých zemích ve 20. století. Praha: Akropolis, pp. 588-589. Rưžička, K. (1948). Kritický měsíčník, 9(2), p. 187. Vma (= Šmucar, V.) (1974). K tvưrčím pětašedesátinám F. Kafky. Věstník židovských náboženských obcí v Československu, 36(11), pp. 3-4. Träger, J. (1969). Publicista spisovatel. Věstník židovských náboženských obcí v Československu, 31(12), pp. 3-4. Tywoniaková, J. (1989). František Kafka a Českolipsko. Českolipsko literární, 9, pp. 29-41. Žantovský, J. (1992). František Kafka. Roš chodeš, 54(1), pp. 12-13. 